\title{
Pemahaman Aktivis GBI Kapten Tendean Tentang Perlengkapan Rohani Orang Percaya Berdasarkan Teks Efesus 6 :10-18
}

\author{
Andreas Budi Setyobekti \\ SEKOLAH TINGGI TEOLOGI BETHEL JAKARTA \\ budisetyobekti7@gmail.com
}

\begin{abstract}
Understanding of Activists GBI Captain Tendean About Believers' Spiritual Supplies Based on the Text of Ephesians 6: 10-18.The purpose of this research is to exegesis the text of Ephesians 6: 10-18 to get its meaning to be used as a theological basis for discovering the extent of activist / minister's understanding of the spiritual equipment of believers. The research method used is a qualitative by exegese method Ephesians 6: 10-18 and applying it to gain an understanding of activists / servants through survey using Google Form tools. The results of his research are: part of activists at GBI Captain Tendeaan do not understand correctly the meaning of the spiritual equipment of believers properly and correctly. Some of them do not apply the meaning of the spiritual equipment of believers in their daily lives. Recommendation: The church needs to have more prayer meetings in the middle of the week and activists have understood the importance of evangelism so evangelistic practices are needed that involve all members of the congregation and activists.
\end{abstract}

Keywords: understanding of activis; believers' spiritual equipment ; Ephesians 6: 10-18.

\begin{abstract}
Abstrak
Pemahaman Aktivis GBI Kapten Tendean Tentang Perlengkapan Rohani Orang Percaya Berdasarkan Teks Efesus 6 :10-18.Tujuan dari penelitian ini adalah mengeksegese teks Efesus 6:10-18 untuk mendapatkan maknanya guna dijadikan landasan teologis dalam menemukan sejauh mana pemahaman aktifis/pelayan tentang perlengkapan rohani orang percaya. Metode penelitian yang dipergunakan adalah metode kualitatif dengan mengeksegese Efesus 6:10-18 serta menerapkannya untuk mendapatkan pemahaman aktifis/pelayan melalui survey menggunakan alat bantu Google Form. Hasil penelitiannya adalah : aktivis Tuhan di GBI Kapten Tendeaan belum seluruhnya memahami dengan benar makna dari perlengkapan rohani orang percaya dengan baik dan benar. Sebagian dari mereka tidak menerapkan makna perlengkapan rohani orang percaya dalam keseharian kehidupan mereka. Rekomendasi: Gereja perlu memperbanyak pertemuan doa di tengah minggu dan aktivis telah memahami tentang pentingnya penginjilan oleh karena itu perlu diadakan praktek-praktek penginjilan yang melibatkan seluruh anggota jemaat dan aktivis
\end{abstract}

Kata kunci: pemahaman aktivis ; perlengkapan rohan ; Efesus 6:10-18

\section{PENDAHULUAN}

Sebagai orang percaya, kita menghadapi kenyataan bahwa ada kerajaan lain ( kerajaan si jahat atau kegelapan ) yang berusaha merebut posisi kita untuk keluar dari Kerajaan Allah bahkan berusaha menjadikan kita menyatu sekaligus terlibat dalam kerajaan kegelapan tersebut. Hal tersebut tidaklah mengherankan, karena kedatangan Yesus yang identik dengan datangnya kerajaan Allah menjadi jelas terlihat saat dalam pelayananNya Yesus harus bertemu dengan kuasa kegelapan yang berupaya mengikat dan membelenggu mereka sehingga didapati beberapa orang mengalami sakitpenyakit dan kerasukan setan. 
Adanya pengaruh dari kuasa gelap yang berusaha mencengkram dan menghancurkan kehidupan manusia membuat kita harus berhati-hati dan waspada, bahkan Paulus mengupas lebih lanjut untuk kita tetap bertahan dan harus berjuang melawan kuasa tersebut.

Dalam berteologi iman harus dibangun berdasarkan kebenaran dalam Alkitab. Iman tidak bisa dibangun hanya berdasarkan pengalaman belaka. Pengalaman orang percaya seharusnya sebagai bukti dari pemahaman iman yang benar dalam Alkitab. Pemahaman yang salah tentang peperangan rohani yang didasarkan pada pengalaman pribadi perlu kita renungkan kembali. Dampak negatif secara psikologis dari peperangan rohani yang didasarkan pada pengalaman pribadi menimbulkan pro dan kontra dikalangan orang percaya sendiri.

Sebagian aktivis jemaat GBI Kapten Tendean tidak berlatar belakang pendidikan Teologi, sehingga ada kemungkinan mereka kurang memahi secara mendalam konteks perlengkapan rohani orang percaya. Terlebih topik ini jarang sekali dikhotbahkan kepada mereka, padahal topik ini sangat penting diketahui dan dipahami oleh mereka, sehingga mereka memiliki kesiapan secara rohani terutama dalam doa sehubungan dengan pelayanan mereka.

Oleh karena itu , peneliti tertarik untuk memaparkan suatu tinjauan teologis dari tulisan Paulus yang terdapat dalam Efesus 6:10 -20, sehingga kita bisa belajar dan merefleksikan dalam kehidupan kita sebagai orang percaya.

Peneliti ingin mengetahui sejauh mana pemahaman aktivis GBI Kapten Tendean mengenai perlengkapan rohani orang percaya sehingga bisa diterapkan dalam kehidupan sehari-hari maupun dalam pelayanan mereka.

\section{METODE PENELIAN}

Dalam penelitian ini peneliti menggunakan penelitian kualitatif dengan cara : mengeksegese Efesus 6 : 10-18 guna menemukan konsep perlengkapan rohani orang percaya untuk dijadikan sebagai landasan teologis guna mendapatkan gambaran pemahaman keadaan aktifis/pelayan GBI Jemaat Kapten Tendean.

\section{Lokasi dan waktu peneitian.}

Lokasi penelitian di GBI Kapten Tendean 10 Mampang Prapatan, Jakarta Selatan. Waktu penelitian maret 2020 - juni 2020. Subyek dan Obyek Penelitian.

Subyek penelitian adalah peneliti dan obyek penelitian adalah aktifis/pelayan GBI jemaat Kapten Tendean.

\section{Sampel dan sumber data penelitian.}

Sampel dan sumber data penelitian adalah seluruh aktifis/pelayan GBI Kapten Tendean yang terdiri dari : kelompok asaf (pemuji dan pemain music), usher, kolektan, bendahara, sekertaris, diakonia dan pemerhati sebanyak 52 orang. Peneliti melakukan wawancara kepada mereka dengan mengisi google form. Hasil survey akan diolah dan selanjutnya akan dipaparkan pada bagian hasil penelitian dan pembahasan. Dari hasil penelitian dan bahasan, peneliti akan membuat kesimpulan, saran dan refleksi.

\section{Teknik Pengumpulan Data.}

Peneliti menggunakan teknik pengumpulan data dengan du acara yaitu observasi sejak bulan maret sampai Juni 2020. Dengan wawancara dimana pertanyaan wawancara adalah hasil eksegese peneliti dari Efesus $6: 10-18$ tentang perlengkapan senjata Allah bagi 
orang percaya. Pelaksanaan wawancara dibantu dengan menggunakan Google Form mengingat PSBB masih diberlakukan sampai penelitiaan ini berlangsung.

\section{HASIL DAN PEMBAHASAN}

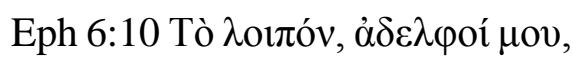

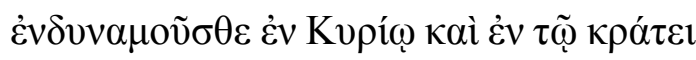

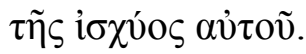

Eph6:11 $\quad \dot{\varepsilon} v \delta v ́ \sigma \alpha \sigma \theta \varepsilon \quad \tau \grave{\nu} v$

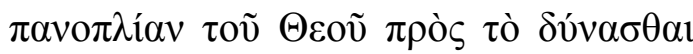

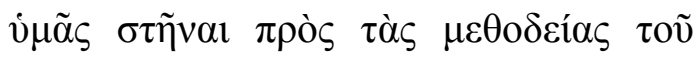
$\delta 1 \alpha \beta{ }^{\prime} \lambda \mathrm{ov}^{*}$

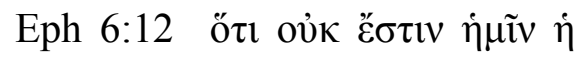

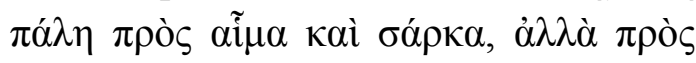

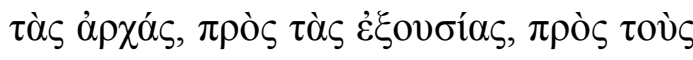

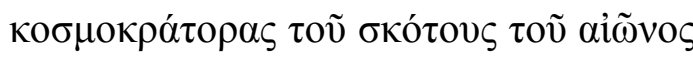

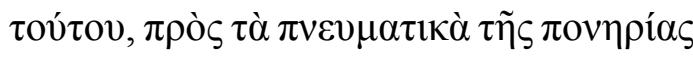

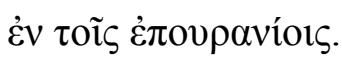

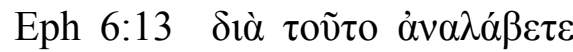

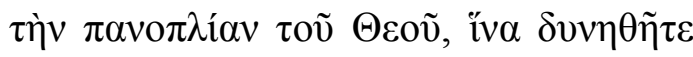

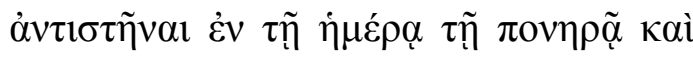

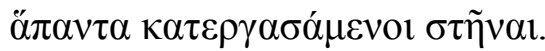

Eph 6:14 $\sigma \tau \tilde{\eta} \tau \varepsilon \quad$ ỡv

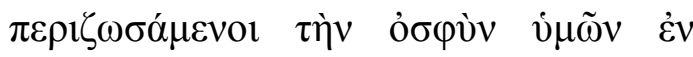

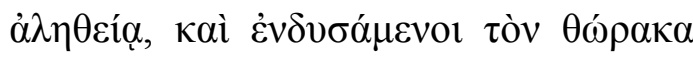

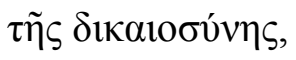

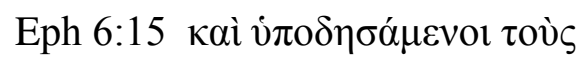

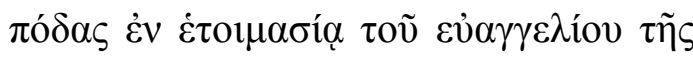

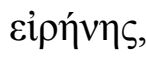

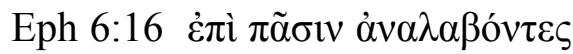

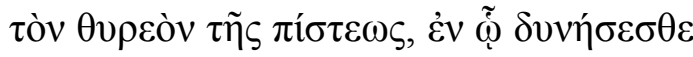

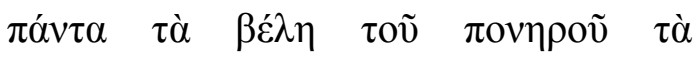
$\pi \varepsilon \pi v \rho \omega \mu \varepsilon ́ v \alpha \sigma \beta \varepsilon \dot{\sigma} \sigma \alpha$.

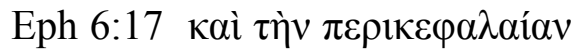

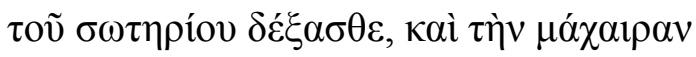

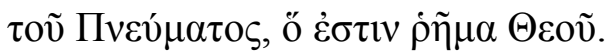

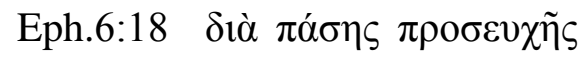

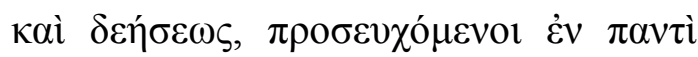

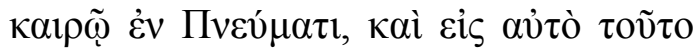

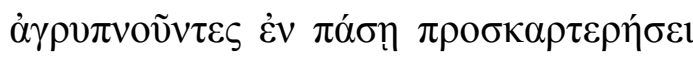

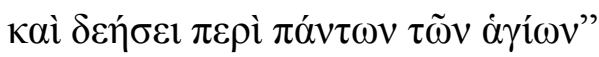

\section{PAPARAN.}

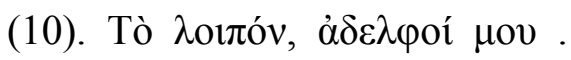
Dengan menggunakan kata adelpoi "saudara" menunjukkan kedekatan Paulus dengan jemaat Efesus. Ini adalah kata-kata peringatan yang ditujukan Paulus kepada jemaat Efesus terutama mereka-mereka yang sedang bertumbuh didalam Tuhan.

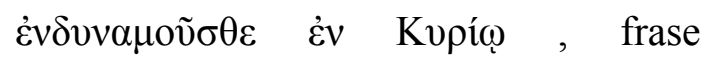
"endunamouste" jenis kata present passive imperative of endunamōo, dari kata kerja " dunamis, to empower"- kata perintah pasif yang mengharapkan jemaat untuk terus menerus kuat di dalam Tuhan. Atau senantiasa tetap kuat di dalam Tuhan dan kuat kuasaNya.

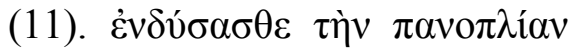

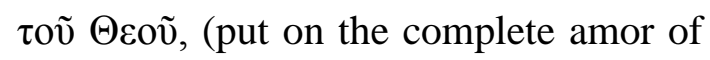
God),Put on (mengenakan), Paulus menggunakan kata ini dengan mensejajarkan pengertiannya seperti seorang yang mengenakan baju untuk menutupi seluruh tubuhnya. Demikian juga dikehendaki untuk setiap orang percaya mengenakan seluruh perlengkapan senjata Allah untuk melindungi dirinya dan mampu berdiri $(\sigma \tau \tilde{\nu} v \alpha)$ melawan apa ? . Dalam frase selanjutnya dikatakan " $\pi \rho \grave{s} \varsigma$ $\tau \grave{\text { à }}$

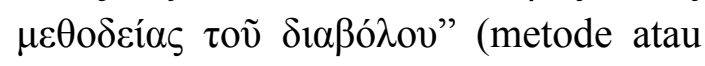
strategi iblis). Dalam Alkitab TBI dikatakan "melawan tipu muslihat Iblis". Metode atau strategi atau tipu muslihat Iblis selalu berorientasi negatif, dimana metode atau tipu muslihat itu selalu mengarah kepada menghancurkan atau membinasakan orang percaya. Orang percaya harus benar-benar memahami bahwa musuhnya adalah iblis dengan strategi atau metodenya berupa tipu dayanya berusaha menghancurkan orang percaya.

$\pi \rho o ̀ \varsigma ~ \tau o ̀ ~ \delta v ́ v \alpha \sigma \theta \alpha \imath ~ v j \mu \tilde{\varsigma} \varsigma \sigma \tau \tilde{v} v \alpha l$.(That ye may able to stand), "Pros 
to"menunjukkan " tujuan" dengan kata benda "dunasthai" dan kata "stenai" yang berjenis 2nd Aorist active infinitive dari kata "histemi" menggambarkan sebuah keadaan orang percaya yang harus selalu berdiri teguh dan tetap bertahan dalam melawan tipu muslihat iblis.

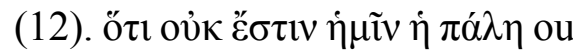

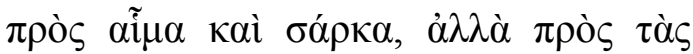

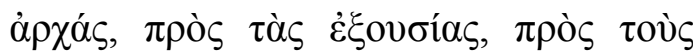

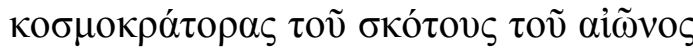

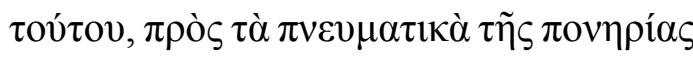

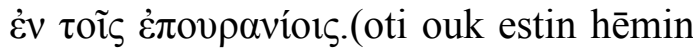
hē palē). "To us the wrestling is not." Palē berasal dari kata pallo, to throw, to swing (melempar atau mengayun ) kata ini berhubungan dengan ayat diatas dimana senjata-senjata itu harus dilemparkan atau diayunkan terhadap musuh-musuh

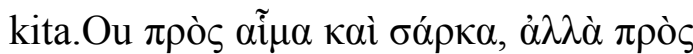
$\tau \grave{\alpha} \varsigma$ à $\rho \alpha ́ \varsigma$ (not against flesh and blood),tidak melawan daging dan darah, tidak melawan sesuatu yang kelihatan mata .

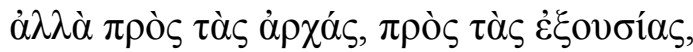

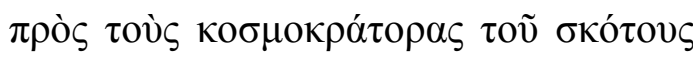

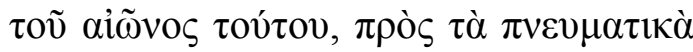

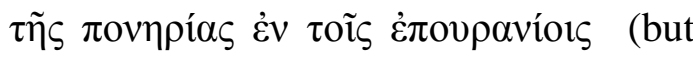
against principalities, against powers, against the rulers of the darkness of this world, against spiritual wickedness in high places.) . Yang menjadi musuh kita adalah pemerintah-pemerintah, penguasa dan penghulu dunia, dan melawan rohroh jahat di udara.

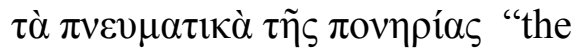
spiritual things of wickedness." Ponērias (from ponēros) is depravity. Setan disebut sebagai " penguasa dunia atau penguasa kegelapan". Dalam tulisan gnostik disebut sebagai "devil-iblis", sedang dalam tulisan rabbinical disebut sebagai "the angle of death- malaikat kematian".

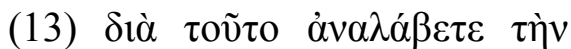

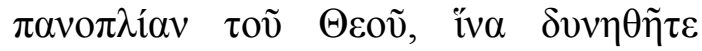

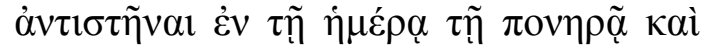

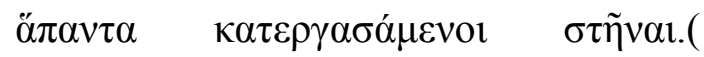
Wherefore take unto you the whole armour of God, that ye may be able to withstand in the evil day, and having done all, to stand.)

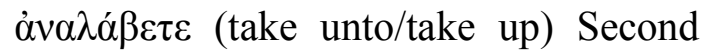
aorist active imperative dari kata analambanō, kata lama digunakan (analabōn) of "picking up" . Kalimat perintah yang dari dulu dan terus menerus harus dilakukan yaitu untuk mengambil seluruh perlengkapan senjata Allah. PB hanya menggunakan kata ini sebanyak $3 x$ yaitu dalam lukas 11;22; efesus 6:11 dan efesus 6:13 yang berarti sebuah bantuan untuk melawan godaan iblis.

Frase ǐv $\alpha v v \eta \theta \tilde{\eta} \tau \varepsilon \dot{\alpha} v \tau \tau \sigma \tau \tilde{\eta} v \alpha \mathrm{l}$ (That ye may be able to withstand ), kalimat akhir "hina" first aorist passive subjunctive dari kata dunamai with antistēnai (second aorist active infinitive dari anthistēmi,berarti to stand face to face, against).Kata benda "stenai" yang berarti kita harus tetap berdiri dan menjadi menang di hari yang jahat.

Bagaimanakah sikap orang percaya agar mampu menang melawan kuasa dan pengaruh si jahat, Paulus memaparkan dalam tulisannya di Efesus pada ayat berikutnya.

(14) $\sigma \tau \tilde{\eta} \tau \varepsilon$ oũv $\pi \varepsilon \rho \iota \zeta \omega \sigma \alpha ́ \mu \varepsilon v o เ$

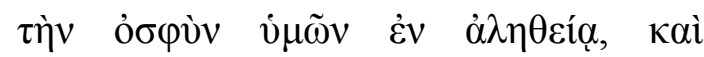

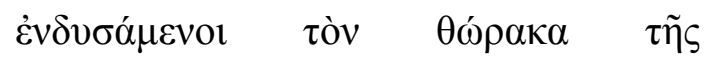

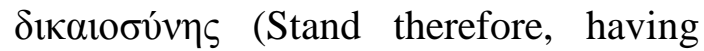
your loins girt about with truth, and having on the breastplate of righteousness)

$\sigma \tau \tilde{\eta} \tau \varepsilon$ o $\tilde{v}$ (stand therefore ) jenis katanya second aorist active imperatif, kata perintah berlangsung dari dulu sampai sekarang yang harus tetap dilakukan ,berasal dari kata "histemi” yang berarti “ 
oleh karena itu harus tetap berdiri. Ini adalah gambaran yang dituntut sehubungan dengan keberadaan seorang prajurit yang siap berperang dimana ia harus dalam kondisi harus tetap berdiri tegap siap menghadapi lawan-lawannya.

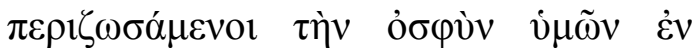

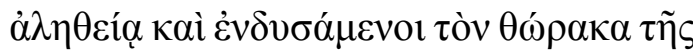

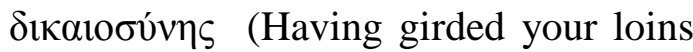
with truth,and having on the breastplate of righteousness ). Berikatpinggangkan kebenaran. Sebagai gambaran dari seorang prajurit Tuhan yang harus tetap mengenakan atau hidup dalam kebenaran dan berbajuzirahkan keadilan. Hal tersebut sebagai metapora dari keberadaan prajurit Tuhan yang harus hidup dalam kebenaran dan keadilan saat mereka harus berhadapan dengan lawannya yaitu si jahat.

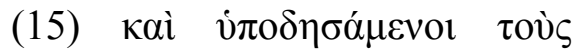

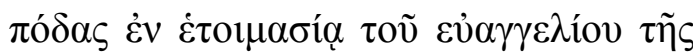

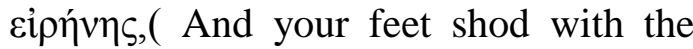
preparation of the gospel of peace)

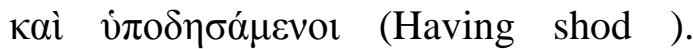
"Having bound under" (sandals). First aorist middle participle dari kata hupodeō, Kasut atau sandal adalah gambaran dari dasar kerelaan seseorang dalam memberitakan Injil damai sejahtera. Yesaya 52:7 mengatakan "Betapa indahnya kelihatan dari puncak bukit-bukit kedatangan pembawa berita, yang mengabarkan berita damai sejahtera dan membritakan kabar baik dan berita selamat".

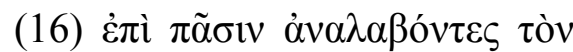

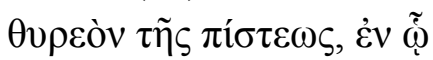

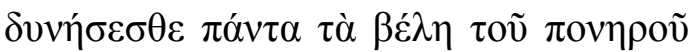

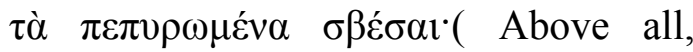
taking the shield of faith, wherewith ye shall be able to quench all the fiery darts of the wicked.)

Frase dalam ayat ini diawali dengan kata "above all" dalam segala keadaan terutama dalam berhadapan dengan si jahat maka "ambilah seluruh perlengkapan senjata Allah (6:13) yang di paparkan oleh Paulus secara terperinci (14-18) yaitu :

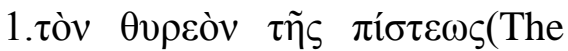
shield of faith). Perisai Iman.Seorang prajurit yang maju dalam pertempuran harus melindungi tubuhnya dengan sebuah perisai, sehingga musuhnya tidak bisa melukai tubuhnya. Perisai Iman adalah gambaran dalam sebuah peperangan rohani, sehingga panah api dari si jahat dapat dipatahkan atau dipadamkan dan tidak bisa melukai

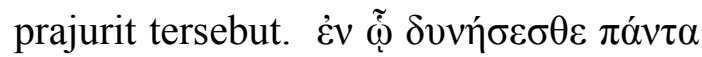

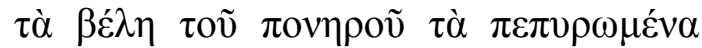
$\sigma \beta \varepsilon ́ \sigma \alpha t$. (Sbesai) First aorist active infinitive of sbennumi, old word, to extinguish (memadamkan), dengan iman kita mampu memadamkan segala panah atau serangan dari si jahat.

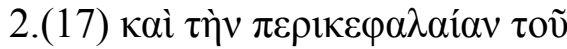
$\sigma \omega \tau \eta \rho i ́ o v ~ \delta \varepsilon ́ \xi \alpha \sigma \theta \varepsilon$, (And take the helmet of salvation).Ketopong keselamatan. Seorang prajurit Romawi yang berperang selalu menggunakan ketopong sebagai alat yang dapat melindungi kepalanya. Paulus mengambilnya sebagai gambaran yang menggambarkan seorang prajurit yang sedang berperang melawan si jahat harus juga mengenakan helm atau ketopong keselamatan.

Serangan dari musuh dapat mengarah ke seluruh bagian dari tubuh seorang prajurit, oleh karena itu Paulus menyinggung alat-alat perlindungan yang sering dipergunakan oleh seorang prajurit dalam berperang. Salah satunya perlindungan untuk kepala adalah ketopong dan dalam hal ini ketopong keselamatan adalah alat perlindungan yang efektif bagi seorang prajurit Allah dalam menghadapi si jahat. 


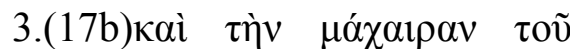

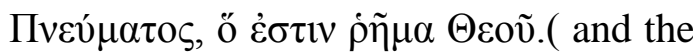
sword of the Spirit, which is the word of God). Pedang yang berasal dari Roh Kudus yang berupa Firman Allah adalah senjata yang ampuh dalam menghancurkan si jahat. Firman Allah adalah senjata yang mematikan jika dipergunakan oleh orang yang benarbenar memahami kuasa Firman tersebut. Saat Yesus menghadapi godaan dari si jahat, Yesus mematahkan godaan godaan tersebut dengan Firman Allah ( Jangan engkau mencobai Tuhan Allah $\mathrm{Mu}$, manusia hidup bukan dari roti saja , tetapi dari setiap firman yang keluar dari mulut Allah, Matius 4:4-7).

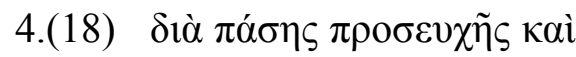
$\delta \varepsilon \eta ́ \sigma \varepsilon \omega \varsigma, \pi \rho \circ \sigma \varepsilon v \chi o ́ \mu \varepsilon v o 1 ~ \varepsilon ̉ v ~ \pi \alpha v \tau i ̀ ~ \kappa \alpha 1 \rho \tilde{~}$

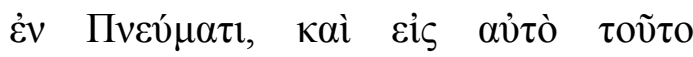

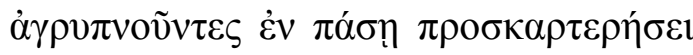

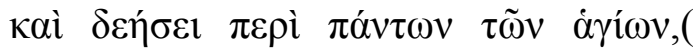
Praying always with all prayer and supplication in the Spirit, and watching thereunto with all perseverance and supplication for all saints).Dalam segala doa dan permohonan. Berdoalah setiap waktu di dalam Roh dan berjaga-jagalah dalam doamu itu dengan permohonan yang tak putus-putusnya untuk segala orang kudus.

\section{Kesimpulan Paparan Eksegese :}

1.Setiap orang percaya dikehendaki untuk senantiasa tetap kuat di dalam Tuhan . Mengapa kita perlu kuat di dalam Tuhan ? Karena Orang percaya harus menghadapi pergumulan dan perjuangan melawan kuasa si jahat dan pengaruh si jahat yang berusaha menghancurkan setiap orang percaya.Perjuangan kita bukan melawan yang kelihatan(darah dan daging), tetapi melawan pemerintah-pemerintah, penguasa-penguasa serta melawan penghulu dunia yang gelap ini yaitu kuasa si jahat.Orang percaya dalam kenyataan hidup harus menghadapi keadaan ini karena sebagaimana kita kitahui bahwa si jahat selalu dan terus menerus berusaha menghancurkan bahkan menarik setiap orang percaya untuk menjadi bagian dan rekan si jahat atau penguasa dunia yang gelap ini.Kesadaran akan keadaan inilah yang memampukan setiap orang percaya untuk selalu kuat di dalam Tuhan.

2.Paulus menyadari bahwa perjuangan atau pertempuran setiap orang percaya hanya mampu dimenangkan jika membiarkan Allah menguasai dan mengontrol kita. Oleh karena itu Paulus mengambil analogi dari seorang prajurit yang harus memperlengkapi dan mempersiapkan diri dalam menghadapi musuhmusuhnya.Kemungkinan gambaran tentang seorang prajurit ini ia dapatkan saat ia berada dalam penjara (20) dimana ia bergaul dan mengamati serta melihat eksistensi seorang prajurit Romawi pada saat itu. Analogi perlindungan diri berupa ikat pinggang yang mengencangkan baju yang dikenakan, baju zirah sebagai rompi untuk melindungi tubuh, alas kaki sebagai perlindungan kaki, perisai sebagai perlindungan dari serangan musuh, ketopong sebagai pelindung kepala dan pedang sebagai senjata dalam berperang adalah gambaran yang lengkap dari apa yang harus dikenakan dan dipergunakan oleh seseorang yang akan dan sedang berperang. Kebenaran, keadilan, kerelaan memberitakan injil, iman, keselamatan,Firman Allah, karya Roh Kudus dan doa adalah sarana bagi setiap orang percaya yang harus tetap dikenakan dan diaktualisasikan dalam menghadapi kuasa dan pengaruh si jahat 3.Paulus menyinggung keseimbangan antara perlindungan diri 
dan alat untuk menyerang musuh. Orang percaya perlu melindungi diri dengan berdiri tegap selalu berjaga - jaga, berikat pinggangkan kebenaran, berbaju zirahkan keadilan , kaki berkasutkan kerelaan untuk memberitakan injil, perisai iman dan gunakan ketopong keselamatan. Dalam menyerang musuh pergunakanlah pedang Roh yaitu Firman Allah dan doa.

4.Berdoa setiap waktu artinya orang percaya harus tetap memiliki hubungan yang intim dengan Tuhan, atau orang percaya harus tetap dalam kondisi berjaga-jaga yang di aktualisasikan dalam doa. Berdoa di dalam Roh artinya berdoa dibawah kontrol Roh Kudus atau orang percaya selalu dipimpin dan terus menerus Roh Kudus menguasai dan mengontrol mereka. Demikian juga kita perlu mendoakan untuk setiap orang kudus agar mereka berada dalam perlindungan Allah.

5.Paulus menutup anjurannya dengan menyinggung keberadaan dirinya (19) agar ia diberikan keberanian untuk membuka mulut dan berkata-kata yang benar sehingga Ia memiliki keberanian untuk memberitakan rahasia Injil. Orang percaya memiliki tugas dan tanggungjawab bukan saja memikirkan diri sendiri tetapi juga harus memikirkan keselamatan orang lain dengan bersedia menjadi pemberita-pemberita Injil Yesus Kristus.

\section{Hasil Survey :}

Peneliti membuat 20 pertanyaan survey lewat google form kepada 52 responden dalam hal ini aktivis di GBI Kapten Tendean. Responden yang menjawab pertanyaan sebanyak 20 orang.

\section{ANALISIS DAN INTERPRETASI DATA}

20 Responden Dari 52 Aktivis di GBI Kapten tendean yang menjawab survey 20 orang, $83,3 \%$ sebanyak 15 responden menjadi aktivis $>5$ th dan $16,7 \%$ sebanyak 5 responden menjadi aktivis $<5$ th. Ada kemungkinan sebagian besar aktivis yang sudah lanjut usia tidak memahami teknologi shg mereka enggan untuk menjawab survey (32).

Sebagian besar aktivis (20) sudah dewasa secara rohani karena mereka sudah melayani Tuhan lebih dari 5 tahun

Kesadaran adanya musuh secara rohani:90\% sebanyak 18 responden menjawab sadar adanya musuh dan $10 \%$ sebanyak 2 orang responden menjawab tidak sadar. Sebagian besar aktivis menyadari adanya musuh yang tidak kelihatan dalam pelayanan mereka.

Pemahaman thd teks Ef 6:10-18 :80\% sebanyak 16 responden menjawab memahami dan 20\% sebanyak 4 responden menjawab tidak pahamSebagian besar aktivis memahami teks Ef 6:10-18 dan sebanyak $20 \%$ tidak paham hal tersebut dikarenakan mereka jarang membaca teks tersebut.

Alasan harus kuat di dalam Tuhan: $65 \%$ sebanyak 13 responden menjawab untuk menghadapi kuasa iblis dan $35 \%$ sebanyak 7 responden menjawab agar tdk jatuh kedalam dosa

Sebagian besar aktivis sudah memahami Teks Efesus 6:10-18 sesuai yang dituliskan Paulus.

Pengertian musuh org percaya:100\% sebanyak 20 responden menjawab iblis dan penghulu dunia yg gelap iniMereka memahami bahwa musuh org percaya adl iblis bukan kepercayaan atau agama lain dalam hal 
ini bahaya akan SARA dapat diminimalkan.

Perlunya perlindungan dan perlengkapan rohani: 95\% sebanyak 19 responden menjawab setuju, dan 5\% sebanyak 1responden menjawab raguragu Sebagian besar aktivis menyadari tentang perlunya perlindungan serta perlengkapan rohani dlm pelayanan

Arti ikat pinggang dlm Efesus: $69 \%$ sebanyak 18 responden menjawab kebenaran dan $10 \%$ sebanyak 2 responden menjawab keadilan Sebagian besar aktivis memahami pengertian ikat pinggang dalam efesus 6 dengan benar.

Arti baju zirah dlm Ef.6:

90\% sebanyak 18 responden menjawab keadilan dan $10 \%$ sebanyak 2 responden menjawab kebenaran Sebagian besar aktivis memahami pengertian baju zirah dalam efesus 6 dengan benar.

Arti Alas kaki dlm Ef 6.: $100 \%$ sebanyak 20 responden menjawab kerelaan untuk memberitakan InjilSeluruh responden memahami dengan benar pengertian alas kaki dalam Eff.6

Arti perisai dlm Ef.6: $100 \%$

sebanyak 20 responden menjawab iman Seluruh responden memahami dengan benar pengertian perisai dalam Ef 6 .

Arti ketopong dlm Ef.6: 90\% sebanyak 18 responden menjawab keselamatan, $5 \%$ sebanyak 1 orang menjawab iman dan 5\% sebanyak 1 orang menjawab kebenaran. Hampir sebagian besar responden memahami dengan benar pengertian ketopong sementara 2 orang tidak memahami tentang ketopong dlm Efesus 6.

Arti pedang Roh dlm Ef.6: 90\% sebanyak 18 responden menjawab Firman dan $10 \%$ sebanyak 2 responden menjawab keselamatan

Sebagian besar responden memahami dengan benar pengertian pedang Roh dalam Efesus 6

Pemahaman pengertian analogi prajurit: $\quad 85 \%$ sebanyak 17 responden menjawab berdiri tegap dan berjaga-jaga, 15\% sebanyak 3 responden menjawab tunduk kepada pemimpin Hampir sebagian besar aktivis memahami analogi prrajurit yang diberikan Paulus, sedang 3 responden menafsirkannya secara harafiah.

Kesiapan dlm menghadapi iblis.:85\% sebanyak 17 responden menjawab tidak, sedangkan $15 \%$ sebanyak 3 responden menjawab raguragu Walaupun sebagian besar aktivis tidak takut thd serangan iblis , namun ada 3 responden masih merasa ragu-ragu.

Respon thd serangan iblis: $85 \%$ sebanyak 17 responden menjawab tidak, sedangkan $15 \%$ sebanyak 3 responden menjawab ragu-ragu Walaupun

sebagian besar aktivis tidak takut thd serangan iblis, namun ada 3 responden masih merasa ragu-ragu.

Bentuk serangan Iblis:65\%

sebanyak 13 responden menjawab sakit penyakit, $30 \%$ sebanyak 6 orang menjawab kemalasan dan 5\% sebanyak 1 responden menjawab ketidak suksesan Aktivis tidak memahami dengan benar pengertian dari serangan iblis krn: sakit penyakit bisa disebabkan oleh human error, kemalasan adalah tabiat dan tidak sukses berhubungan dengan etos kerja.

Pemahaman thd siapa yang perlu didoakan: $\quad 80 \%$ sebanyak 16 responden menjawab segala orang kudus, $10 \%$ sebanyak 2 responden menjawab diri sendiri dan keluarga dan $10 \%$ sebanyak 2 responden menjawab bangsa dan negara Masih ada aktivis yang belum memahami maksud Paulus untuk 
meminta didoakan, sebanyak 4 responden menjawab tidak benar.

Arti berdoa setiap waktu:

$100 \%$ sebanyak 20 responden menjawab memiliki hubungan yang intim dengan Allah Seluruh aktivis memiliki pemahaman yang benar

Memiliki waktu khusus berdoa:72,2\% sebanyak 13 responden menjawab ada, 5 menjawab kadangkadang dan 2 orang menjawab tiad adaSebagian aktivis memiliki jam khusus berdoa yang lain masih kadang-kadang dan tidak memiliki jam doa

Makna doa bagi aktivis: $90 \%$ sebanyak 18 responden menjawab menjalin keintiman dengan Allah, 10\% sebanyak 2 responden menjawab kewajiban sblm pelayanan Sebagian besar aktivis memahami makna doa dengan benar

Tugas penginjilan dalam Efesus $6 .: 100 \%$ sebanyak 20 responden menjawab semua orang Seluruh aktivis telah memahami secara konseptual ttg tugas penginjilan, apakah praktikalnya juga demikian?

\section{SIMPULAN DAN REKOMENDASI KESIMPULAN}

Aktivis/pelayan Tuhan di GBI Kapten Tendeaan belum seluruhnya memahami dengan benar makna dari perlengkapan rohani orang percaya dengan baik dan benar.(jawaban dalam tiap pertanyaan tidak $100 \%)$

Sebagian dari mereka tidak menerapkan makna perlengkapan rohani orang percaya dalam keseharian kehidupan mereka: ada sebagian yang jarang membacn aktivis.a teks Firman Tuhan, ada keragu-raguan terhadap serangan iblis, tidak memahami dengan benar bentuk serangan iblis dalam keseharian dan masih memikirkan didoakan untuk kepentingan pribadi dan ada sebagian aktivis yang kadang-kadang berdoa.

Secara teoritis mereka memahami arti doa setiap waktu (100\%) namun tidak mempraktekannya dalam kehidupan sehari-hari.

\section{REKOMENDASI}

Gereja perlu memperbanyak pertemuan doa di tengah minggu.

Aktivis telah memahami tentang pentingnya penginjilan (100\%)oleh karena itu perlu diadakan praktekpraktek penginjilan yang melibatkan seluruh anggota jemaat dan aktivis 


\section{DAFTAR PUSTAKA}

Blast,

Horst

and

Schneider,Gerhard.(1991).

Exegetical Dictionary of The

New Testament vol.1,Grand

Rapids ,Michigan : William B.

Eerdamns Publishing Company.

Testament, Downer Grove, Illinois : Intervarsity Press.

Markus, Barth .(1974). Ephesians : Introduction, Translation, and Commentary on Chapter 1-3, Garden City, New York: Doubleyday and Company,Inc.

Richardson,Allan.(1990). A Dictionary of Christian Theology, Philadelphia : The Westminster Press.

Sugiono. (2010).Metode penelitian Kuantitatif, Kualitatif dan $R \& D$ ,Bandung: Penerbit Alfabeta.

Schnelle Udo.(1998). The History and Theology of the New Testament
Green ,Jay P.(1986) The Interlinier Bible Hebrew-GreekEnglish,With strong's Concordance Numbers Above Each Word, Massachusetts: Hendrickso Publisher.

Keener, Craig S(NY). The IVP Background Commentary New Writings, London: SCM Press LTD.

Kadjakoro, Y. O. (2019). Konsep Prajurit Allah berdasarkan Efesus 6:10-20 dan Implementasinya dalam Kehidupan Orang Percaya. JIREH- Jurnal Ilmiah Religiosity Entity Humanity , 40-52.

Lo, T. (2012). Kenali Diri, Kenali Musuh, Gunakan Strategiyang Tepat : Pengajaran Tentang Peperangan Rohani Menurut Surat Efesus. Veritas : Jurnal Teologi dan Pelayanan, 159172. 